\title{
SOLUTIONS TO CREATE INCOME DURING COVID-19 FOR KARAMG TARUNA PASIRWANGI UJUNGBERUNG
}

\author{
Jajat SUDRAJAT ${ }^{*}$, Wahyu SARDJONO ${ }^{2}$, and Meiryani MEIRYANI ${ }^{3}$ \\ ${ }^{1}$ BINUS Entrepreneurship Center, Management Department, BINUS Business School Undergraduate Program \\ Bina Nusantara University, Jakarta, Indonesia \\ ${ }^{2}$ Information Systems Management, Binus Graduate Program, Bina Nusantara University, Jakarta, Indonesia \\ ${ }^{3}$ Accounting Department, Faculty of Economics and Communication, Bina Nusantara University, Jakarta, Indonesia \\ 1*jsudrajat@binus.edu, ${ }^{2}$ wahyu.s@binus.ac.id, ${ }^{3}$ meiryani@binus.edu
}

\begin{abstract}
As an effort to revitalize the Indonesian economy that has been affected by the Covid-19 pandemic, one of the efforts that can be done is to build a collaborative network of startups and technopreneurs that aims to support a better technology-based entrepreneurial ecosystem by creating structured programs that can create wider employment opportunities. and provide assistance, training, and facilitation of the needs of technopreneurs. Efforts to support and succeed in government programs during the Covid-19 pandemic are providing assistance in community service programs, namely through the Karang Taruna Community and Students of Pasirwangi Ujungberung Village, Bandung with the theme "Solutions to Create Income for the Karang Taruna Community in Pasirwangi Ujungberung Village". The results of the implementation of this program are very beneficial and have a positive impact, especially on people who have lost their jobs so they do not get an income, with the "Intensive Work" program method building infrastructure facilities to get continuous income opportunities. Karang Taruna members receive direct wages from the labor-intensive program activities to build coffee shops and other infrastructure such as parking lots to serve the healthy walking sports community and the cycling community every morning, on Saturdays and Sundays or holidays. Karang Taruna members get income opportunities by selling pure milk and coffee and other snacks provided at the shop.
\end{abstract}

Keywords: Labor Intensive, Community, Covid-19 Pandemic, Coffee Shop, Income Opportunity

\section{BACKGROUND}

The Karang Taruna Community and Students of Pasirwangi Urban Village, Bandung City consist of factory employees, entrepreneurs and creative industry employees, unemployed due to layoffs, construction workers, agricultural workers, alumni of well-known universities and other professions, are the resources owned by the Pasirwangi Village, plus road infrastructure. already in the concrete, the view of the rice fields and the fresh air is a gift from God Almighty that has not been optimized. They must be guided and given the opportunity in an open space to collaborate to produce a product in the form of goods or services. The following is one of the facilities and infrastructure available in one of the areas of Pasirwangi Village, namely the Means of View of Rice Fields and Mountains as Attractions for Selfies.

Every morning, especially on Saturdays and Sundays, many people do walking, jogging, cycling through this road, and it is certain that every visitor wants to take pictures in front of the view. This place has its own charm, because in the area along the road there are very few places like this, various residents from the city of Bandung who want to enjoy the fresh air and sports, this place is an alternative, especially for employees who are bored at home WFH looking for a place that is not too crowded. crowded and safe because the air is not blocked directly from Mount Manglayang.

This area is a resting place for passers-by, even though they have to sit on the ground while looking at the view of the mountains and rice fields.

The bicycle lover community always passes this area to tourist attractions in Lembang and other places, they often get off their bicycles because this area is an uphill road, except for people who are young and have experience riding bicycles, they smile happily while enjoying the scenery and of course take time to take photos in this area. This area is about 3 KM from the location of the object of the Community Service Program (PkM), this place is managed by the Bandung City Park Service, this tourist spot is free for people who want to exercise and enjoy the view of the East Bandung View, especially the West Java Floating Mosque which is clearly visible from the place. This, especially at night, can see the view of the twinkling lights. This area has a good road, wider than the PkM object, and is connected by a smaller road to the PkM object, which is very safe for those who want to jog towards this place.

Various government policies in dealing with the Covid-19 pandemic, especially the Ministry of Education and Culture as well as other Ministries seek to make policies for the benefit and protection of the wider

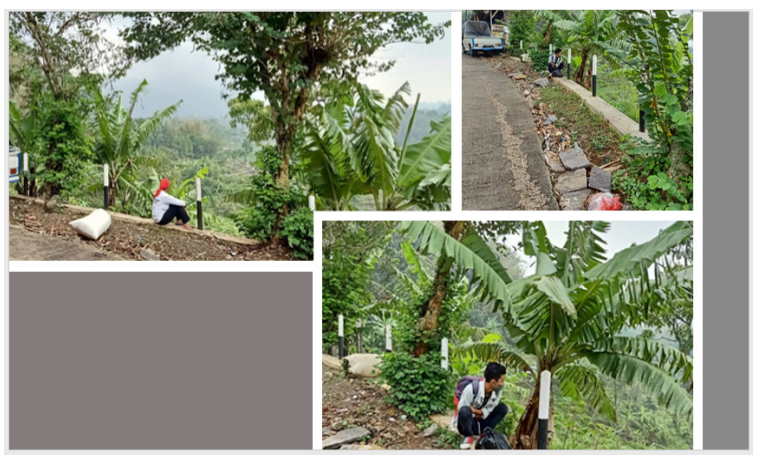

Figure 1. Visitors Enjoying the Scenery Without Seating Facilities 
community. Such as the Ministry of Social Affairs, the Ministry of Cooperatives and other Ministries. As an effort to revitalize the Indonesian economy that has been affected by the Covid-19 pandemic, one of the efforts that can be done is to build a collaborative network of startups and technopreneurs that aims to support a better technologybased entrepreneurial ecosystem by creating structured programs that can create wider employment opportunities. and provide assistance, training, and facilitation of the needs of technopreneurs. Aware of this urgency, the Ministry of Research and Technology/BRIN together with the INOTEK Foundation agreed to establish a collaboration which was marked by the signing of a memorandum of understanding for the Thousand Technopreneur Program in a Million Jobs (STSP)(Biro Kerja Sama dan Komunikasi \& Kemenristek/BRIN, 2020). Inspired by Policy Government through the Ministry of Research and Technology/BRIN. Other government policies The government has budgeted a total of Rp7.21 trillion for quota subsidies for students and students for Distance Learning (PJJ) or online due to Covid-19. As for the quota budget for teachers, it is currently being calculated by the Ministry of Education and Culture (Kemendikbud) (Kemenkeu, 2020). The Ministry of Finance approved educational funding assistance in the form of credit for students, students, teachers and lecturers in the country who do online learning from home.

In the midst of the pandemic era, every country is required to optimize the potential of all its economic resources so that the economy continues to run and minimize the impact of Covid-19 on the business world. Many businesses find it difficult to get access to capital, have experienced a decline in demand, have been forced to cut operational funds, and even have to lay off their employees. Entrepreneurial activities play an important role for the economic recovery phase as well as support national economic growth. Entrepreneurs play a role in creating added value of natural resources, creating new jobs in various fields, increasing national income and reducing economic and social inequalities. Currently, there are several opportunities that can be exploited by the business world to face the era of adaptation to new choices, by utilizing technology and digital aspects.

The Thousand Technopreneurs One Million Jobs Program is a collaborative entrepreneurship program to create a network of technopreneurs in 34 provinces in Indonesia with appropriate entrepreneurial model methods linked to investors and technology-based partnerships and $\mathrm{RnD}$. This program has a social and economic impact, by creating more than 1000 new Technopreneurs who will start the local economy at the MSME level and help contribute to increasing local GDP and also open access to national and global markets and create direct jobs for more than 1,000 technopreneurs. and more than 1 million indirect jobs (upstream and downstream). The aim of the program is to leverage technology for national and global markets that will be connected across provinces based on sector, skills, market alignment, etc. The program nationally starts from the level of the Kelurahan Karang Taruna Community. Based on the opportunities and challenges as well as the policy of providing quotas for lecturers and students mentioned above, the role of students as a liaison between lecturers and MSMEs and the community in the closest environment to students is an important strategy to be optimized by implementing and synchronizing the teaching and community service process, especially in entrepreneurship courses that have been and are being studied by students of various study programs throughout Indonesia. Being an entrepreneur is difficult, you need to prepare physically and mentally as well as spiritually, but an entrepreneur can be a hero for others because many people and even thousands of families get jobs.(Sudrajat, 2018). This is the time for all of us to work seriously and seriously by doing pentahelix collaboration with all partners, namely Academics, Business, Community, Finance, Government, and Media. Campus research must be oriented to the real needs that exist in society and industry.(Herlina, 2021). Pasirwangi Village is a sub-district in Bandung City, which is one of the fostered villages that will be developed into a Tourism Destination location by utilizing the potential that exists in the Pasirwangi village. We, from the Binus lecturer team, will be one of the agents of change, as has been done in Pasirmulya village, Bandung regency (Ghazali et al., 2021).

\section{METHOD}

This paper was compiled through a literature review and collection of information sources that was carried out in practice by looking for data on the number of Karang Taruna communities laid off due to the impact of Covid 19. Contacting the Head of RT and Head of RW in Pasirwangi Ujungberung Village, Bandung to get a cover letter to Pasirwangi Village and contact the Kelurahan Pasirwangi. The main purpose of this paper is to obtain information on the impact of covid-19 and follow up to find solutions in collaboration with various related parties, namely:

1. Coordination with students majoring in DKV Interior Design to prepare sketches of seating plans and other equipment.

2. Carry out walking activities around the $P k M$ location to see other opportunities to collaborate and find inspiration for equipment that will support the PkM object location.

3. Gather information sources from the internet and combine it with your own experience.

4. Identify and summarize information from the literature in a structured way

\section{RESULT AND DISCUSSION}

The Karang Taruna Community and the Pasirwangi Urban Village Students, Bandung City and the Binus 
lecturer team can work together to build infrastructure as a solution to overcome unemployment due to layoffs. The collaboration of builders, agricultural workers, alumni of well-known universities and other professions, is a resource owned by the Pasirwangi Village, plus the road infrastructure that has been concreted, views of rice fields and fresh air is a gift from God Almighty that can be utilized. The following is one of the facilities and infrastructure available in one of the Pasirwangi Urban Village areas that has begun to be optimized, namely as follows:
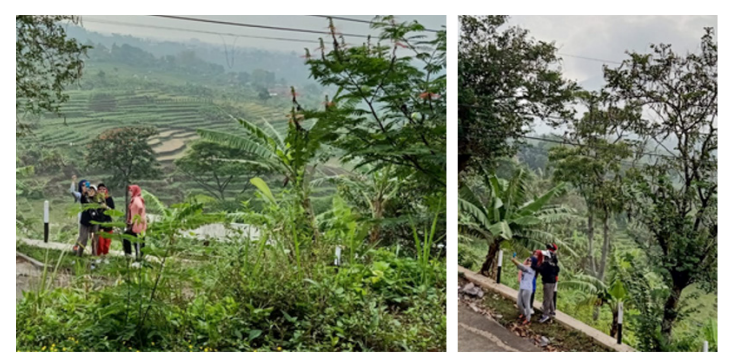

Figure 2. Means of View of Rice Fields and Mountains as an Attraction for Selfies

Every morning, especially on Saturdays and Sundays, many people do walking, jogging, cycling through this road, and it is certain that every visitor wants to take pictures in front of the view. This place has its own charm, because in the area along the road there are very few places like this, various residents from the city of Bandung who want to enjoy fresh air and sports, this place is an alternative, especially for employees who are bored at home WFH looking for a place that is not too crowded and safe because the air is not blocked directly from Mount Manglayang.

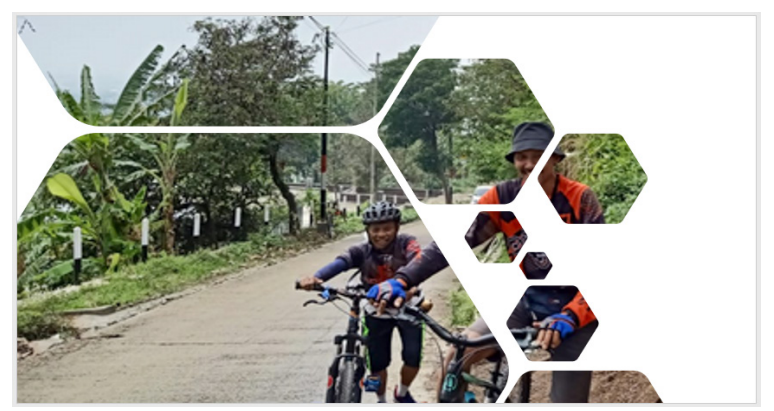

Figure 3. Road and Scenic Facilities Suitable for Cycling Hobby

The bicycle lover community always passes this area to tourist attractions in Lembang and other places, they often get off their bicycles because this area is an uphill road, except for people who are young and have experience riding bicycles, they smile happily while enjoying the scenery and of course take time to take photos in this area.

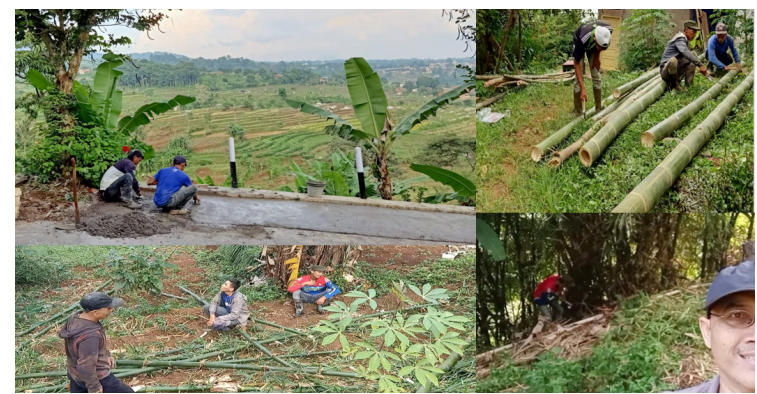

Picture. 4. Infrastructure creation process

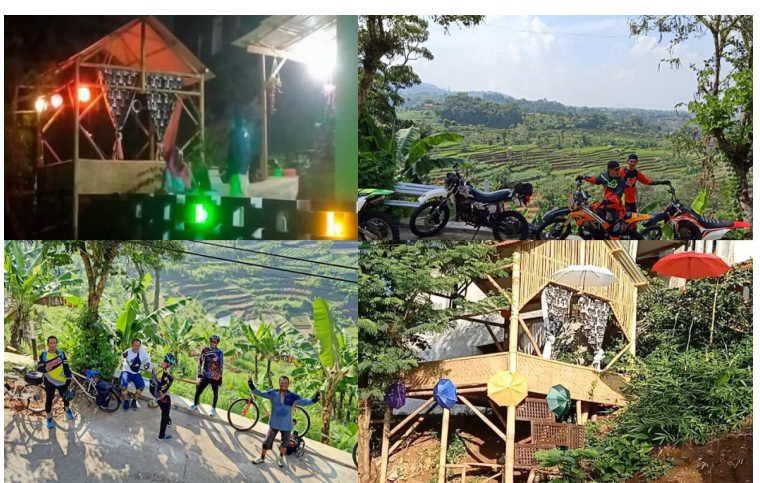

Picture 5. Infrastructure facilities that have been built; parking lot, hut/shop and seating.

\section{CONCLUSION}

Solutions to problems for residents affected by layoffs. They are empowered in labor-intensive activities to organize the area to become a Tourism Village area, one of which is to create and build infrastructure. The design and construction of the facilities were designed by the students of DKV Interior Design. The implementation of laborintensive work as a solution to earn income is from the wages of "Intensive Work" workers and buying supporting building materials from local residents, by utilizing bamboo trees that are widely available in the area. This project as a pilot project to inspire other Ministries in implementing assistance to the community directly, not only Direct Cash Assistance (BLT), can be consumed. There is a need for collaboration between the relevant Ministries and Offices, so that the sustainability of income will be seen clearly, taking advantage of the current Covid-19 condition, there are many opportunities that we can work on together, even though this project is not perfect, at least there is a solution that can be followed up in the year next project.

\section{REFERENCES}

Biro Kerja Sama dan Komunikasi, \& Kemenristek/ BRIN. (2020). Kemenristek/BRIN dan Yayasan INOTEK Tanda Tangani Nota Kesepahaman: Ciptakan Seribu Teknopreneur Sejuta Pekerjaan. Kemenristek/BRIN. https://www.brin.go.id/ kemenristek-brin-dan-yayasan-inotek-tandatangani-nota-kesepahaman-ciptakan-seributeknopreneur-sejuta-pekerjaan/

Ghazali, H., Hidayat, Z., Dewanti, R., \& Hendarti, H. (2021). The Communication Role of Agents of Change in Binus Bangun Desa in Pasirmulya Village, Bandung. 2nd Southeast Asian Academic Forum on Sustainable Development (SEA-AFSID 2018), 392-395.

Herlina, N. (2021). Kolaborasi Membangun Ekosistem untuk Kedaulatan Indonesia untuk Rekacipta. Https://Dikti.Kemdikbud.Go.Id/. https://dikti. kemdikbud.go.id/kabar-dikti/kabar/kolaborasimembangun-ekosistem-untuk-kedaulatanindonesia-untuk-rekacipta/ 
Kemenkeu. (2020). Kuota untuk Pembelajaran Daring Pelajar dan Mahasiswa Disubsidi Pemerintah Hingga Desember 2020. Kemenkeu.Go.Id. https:// www.kemenkeu.go.id/publikasi/berita/kuota-untuk- pembelajaran-daring-pelajar-dan-mahasiswadisubsidi-pemerintah-hingga-desember-2020/

Sudrajat, J. (2018). Memahami Belajar Entrepreneurship di Perguruan Tinggi. Deepublish. 